\title{
НЕПОДАТКОВІ ДОХОДИ БЮДЖЕТІВ: ФУНКЦІОНАЛЬНЕ ПРИЗНАЧЕННЯ ТА МОЖЛИВОСТІ ЙОГО АКТИВІЗАЦІї
}

\begin{abstract}
Проаналізовано функиіональне призначення неподаткових доходів і виявлено домінування їх фіскальної функиії. Наголошено, щчо подальша ї̈ активізація можлива за умови узгодження фінансових інтересів держави $i$ платників. Компенсаиійне призначення неподаткових доходів доцільно посилити шляхом перегляду їх бази $i$ ставок. 3'ясовано, щуо неподаткові доходи бюджетів як регулюючий інструмент сьогодні використовуються недостатньо. Обгрунтовано напрямки посилення їхнього впливу на соиіально-економічні процеси в Україні.

Ключові слова: державний бюджет, метод формування доходів бюджету, неподаткові доходи бюджетів, фіскальна функиія, компенсаційний характер, регулюючий інструмент.
\end{abstract}

Постановка проблеми. Система фінансових взаємовідносин, у центрі якої - потреби органів влади, в Україні побудована та функціонує особливим чином. Основним джерелом ресурсного забезпечення, базовим цільовим грошовим фондом для фінансування таких потреб є державний бюджет. Тому можливість у запланованому розмірі та своєчасно наповнити саме його коштами визначає спроможність самореалізації та самовідтворення системи державної влади в цілому, іiї центральної й територіальних складових, зокрема. Аргумент на користь такої тези - циклічність активної фази використання бюджетних ресурсів на капітальні потреби розвитку країни та окремих їі територій саме напередодні виборів до органів влади різних рівнів. Відповідно, необхідність повноцінного задоволення загальносуспільних потреб, з одного боку, й досягнення високого ступеня ефективності діяльності органів державної влади та місцевого самоврядування, 3 іншого, зумовлюють потребу застосовувати результативні механізми мобілізації коштів у бюджети різних рівнів.

Стан розвитку національної економіки та соціальної сфери продукує численні ризики як щодо механізмів формування бюджетних ресурсів суспільства, так і щодо зростаючої потреби в їх обсязі. Гострота актуальності фіскальних ризиків в Україні перестала бути предметом фахового інтересу тільки науковців. 3 2019 року органи державної влади зобов'язані оцінювати ступінь їхнього впливу і вживати заходи для його мінімізації [1]. Об'єктивно, пандемія COVID-19 та подібні ій потрясіння змушують більш ретельно й активно управляти фіскальними ризиками [2]. Крім того, реалізація заходів з подолання наслідків пандемії потребує значних обсягів фінансових ресурсів (тільки за період 2 березня - 31 грудня 2020 року на ці потреби в Україні спрямовано 53,146 млрд. грн. [3]). Тому на порядок денний виноситься питання ефективного управління джерелами бюджетних фондів органів влади в Україні.

Традиційний підхід передбачає оптимізацію застосування, насамперед, податкових інструментів формування доходів бюджетів (див., наприклад, [4]). Він зумовлений безсумнівно великою фіскальною роллю податкових надходжень, їхнім різновекторним впливом на базових суб'єктів національної економіки, можливістю активізувати окремі елементи механізму оподаткування. Небажаною, але в кризових умовах прийнятною стає інтенсифікація використання позичкових джерел наповнення центрального бюджету країни (зокрема, за даними ЄЦБ, консолідований борг урядів групи країн ЄС-19 протягом першого півріччя 2020 року зріс з 1,786 до 7,386\% ВВП [5]).

Проте рівень і податкового, і боргового навантаження на економіку має власні раціональні межі. Тому бюджетний механізм мобілізації доходів містить неподаткову компоненту як його обов'язкову складову. Її практичне застосування дозволяє урізноманітнити ("створити більш складну композицію надходжень уряду" [6]) та наростити можливості держави для акумулювання фінансових ресурсів. Потреба виявити їх конкретні напрямки в кризових умовах розвитку національної економіки актуалізує проведення наукових досліджень за цією тематикою.

Аналіз останніх досліджень і публікацій. Неподаткові доходи бюджетів перебувають у сфері наукових інтересів ряду вітчизняних дослідників. Їхню суть і механізм формування вивчали Горин В.П. [7], Дем'янишин В.Г. [8], Касперович Ю.В. [9], Огонь Ц.Г. [10]. Особливу увагу науковці звернули на правову природу 
неподаткових надходжень. Зокрема, Маринчак Є.С. і Якимчук Н.Я. розкрили погляди науковців на правове явище "обов'язкові неподаткові платежі", а також проаналізували підходи до критеріїв їх систематизації [11; 12] та правового регулювання [13]. Грунтовну оцінку складу неподаткових доходів бюджетів в Україні на предмет їх відповідності міжнародним стандартам забезпечили Богдан I.B., Коноваленко Д.В., Юра Т.Ю. [14]. Натомість Дем'янишин В.Г. і Шаманська О.С. [15], Петраков Я.В. [16], Письменний В.В. [17] вивчали результативність справляння неподаткових платежів до бюджетів.

Відзначимо, що увага зарубіжних науковців більше звернена на проблематику впливу неподаткових надходжень бюджетів на економічне зростання (Ванг К., Ванг 3. [18], Жанг С., Хуанг 3. [19]), механізм і стан управління ними (Ямін Н., Амір А., Ангрейні М. [20]), властиві їм фіскальні ризики (Мур Дж., Ройт А. [21]). Також дослідники узагальнювали національні кейси формування неподаткових надходжень бюджетів (наприклад, Іспанії [22], Індії [23], Російської Федерації [24; 25; 26] тощо).

Виділення не розв'язаних раніше частин загальної проблеми. Незважаючи на отримані науковцями результати досліджень, у вітчизняній практиці застосування неподаткових доходів бюджетів протягом останніх років позитивні зрушення недостатньо очевидні. Додатковим чинником посилення актуальності проблематики неподаткових доходів в Україні стала реалізація політики бюджетної децентралізації. Перенесення значного обсягу відповідальності за надання публічних послуг на рівень органів місцевого самоврядування змушує останніх вдаватися до пошуку внутрішньотериторіальних резервів зростання дохідної бази бюджетів, у тому числі за рахунок неподаткових інструментів. Зрештою, у кризових умовах як на центральному, так i місцевому рівнях державного управління акцент робиться на кількісній максимізації бюджетно-ресурсної бази. Тому, віддаючи належне напрацюванням вітчизняних i зарубіжних фахівців, зауважимо потребу подальшого дослідження проблематики функціонування неподаткових доходів бюджетів в Україні у кризових умовах розвитку національної економіки.

Мету дослідження обмежимо розкриттям змісту та функціонального призначення неподаткових доходів 3 наступним виявленням можливостей активізації їх застосування як дієвого фінансового інструменту в умовах посилення ризиків формування доходів бюджетів різних рівнів.

Виклад основного матеріалу дослідження. Під дієвістю фінансового інструменту, сформульованій у меті, насамперед, маємо на увазі прямий кількісний результат його застосування у формі отриманого бюджетом обсягу доходів. Крім того, доцільно врахувати відтерміновані в часі наслідки, які можуть стати продуктом іншого (нефіскального) призначення неподаткових інструментів. Ідеться про регулятивний (стимулюючий чи дестимулюючий) вплив неподаткових доходів бюджетів на їхніх потенційних платників.

Аспекти такого впливу залежать від механізму застосування фіскального інструменту, серед елементів якого базове місце посідають об'єкт і суб'єкт. Від відповіді на запитання «хто і за що повинен перераховувати кошти державі?» залежить фіскальний потенціал такого платежу та, зрештою, прогнозованість обсягу відповідних доходів бюджету. Тому недарма до цього часу триває наукова полеміка щодо трактування змісту неподаткових доходів державного бюджету. Порівняння аргументів i позицій фахівців з фінансів і фінансового права дозволяє зробити такі узагальнення:

- щодо неподаткових платежів до державного бюджету використовується різна термінологія: "неподаткові надходження", "неподаткові доходи", "квазіподатки", "парафіскалітети" [12, с. 3];

- виокремлення неподаткових платежів серед доходів бюджетів пропонується здійснювати за такими критеріями: метод мобілізації $[27$, с. 51-52], пряме або опосередковане збільшення економічних вигод для їх платників [16], суб'єкти процесу акумулювання та зміст операцій - об'єкта неподаткових надходжень [9, с. 55-56];

- сутнісні ознаки неподаткових надходжень як економічної категорії включають: волатильність, обов'язковий i добровільний методи мобілізації $[15$, с. $273 ; 17$, с. 102], відплатний або компенсаційний характер $[15$, с. $273 ; 17$, с. $102 ; 26]$.

Зарубіжні науковці, характеризуючи та класифікуючи надходження державного бюджету, насамперед, посилаються на погляди Селігмана Е. [28]. При цьому використовується термін "неподатковий" ("non-tax") як противага надходженням, які мобілізуються органами влади за допомогою податків, - "обов'язкових внесків особи уряду, щоб покрити витрати, які здійснюються у спільних інтересах, безвідносно до наданих спеціальних переваг" [28]. 
Міжнародна статистика фінансування публічної влади базується на офіційному застосуванні положень Керівництва щодо статистики державних фінансів (Government Finance Stastistics Manual (GFSM, 2014)) [29] та Європейської системи рахунків (The European System of Accounts (ESA, 2010)) [30]. Ретельний аналіз їхнього змісту дозволив виявити відсутність терміна "неподаткові надходження" серед доходів бюджетів урядів. Натомість має місце виокремлення таких груп: податки, соціальні внески, гранти та інші надходження. Імовірно, з метою аналізу й оцінки, як противага податкам, показники трьох останніх груп можуть бути узагальнені терміном "неподаткові надходження".

Саме такий підхід дозволяє трактувати неподаткові надходження бюджетів у широкому сенсі. Його застосування в рамках вітчизняної бюджетної статистики приводить до необхідності врахування, крім другої групи доходів бюджетів, також доходів від операцій 3 капіталом, цільових фондів і офіційних трансфертів. Якщо ж акцентувати увагу на терміні "надходження", то логічно було б долучити платежі, отримувані органами державної влади за розділом "Фінансування бюджету".

3 іншого боку, цей умовивід суперечить чинній практиці застосування вищезгаданих міжнародних стандартів фіскальної звітності. Підтримуючи погляд вітчизняних учених $[14, \mathrm{c}$. 54], основну причину такої ситуації вбачаємо в невідповідності класифікації доходів зведеного бюджету України Керівництву щодо статистики державних фінансів (GFSM, 2014).

Крім того, існують підстави критично оцінювати й назву групи доходів "неподаткові надходження". Вагома сутнісна різниця в трактуванні термінів "доходи бюджету" й "надходження бюджету" [31, стаття 2] випливає 3 поворотності останніх, потенційної або ж фактичної наявності зустрічного потоку вартості (наприклад, у формі відсотків чи майнових активів).

Тому першим кроком до унормування складу доходів бюджетів в Україні та звуження підстав для дискусійності їх тлумачення могло б стати перейменування групи "неподаткові надходження", які обліковуються за кодом 20000000, на "неподаткові доходи". Натомість результат застосування методів та інструментів, які відмітні від податкових, що використовуються для наповнення державної скарбниці коштами (включно 3 трансфертами, позиками тощо), доцільно характеризувати більш загальним терміном "неподаткові надходження". У подальшому саме термін "неподаткові доходи" будемо використовувати, щоб конкретизувати предмет нашого дослідження.

Наукова полеміка 3 приводу трактування суті й формулювання визначення неподаткових доходів, на наш погляд, значно зумовлена їхнім видовим різноманіттям. Зокрема, в Україні протягом минулих років до центрального i місцевих бюджетів справлялося 120 видів таких платежів (таблиця 1).

Кількість видів неподаткових доходів (код 20000000), зарахованих до бюджетів України в 2020 році, од.

\begin{tabular}{|l|c|c|c|c|c|}
\hline \multirow{2}{*}{ Вид бюджету } & \multicolumn{4}{|c|}{ Підгрупа неподаткових доходів: } & \multirow{2}{*}{ Разом } \\
\cline { 1 - 5 } & $\begin{array}{c}\text { доходи від } \\
\text { влас-ності }\end{array}$ & $\begin{array}{c}\text { адміністрат } \\
\text { ивні збори }\end{array}$ & інші & $\begin{array}{c}\text { власні надходження } \\
\text { бюджетних установ }\end{array}$ & 120 \\
\hline Всього, у тому числі: & 30 & 49 & 39 & 2 & 69 \\
\hline Державний бюджет України & 19 & 25 & 25 & - & 32 \\
\hline місцеві бюджети & 6 & 19 & 7 & 2 & 19 \\
\hline спільно & 5 & 5 & 7 & & 2 \\
\hline
\end{tabular}

*Джерело: розраховано за [32].

За даними бюджетної статистики, серед неподаткових доходів найбільш чисельна підгрупа адміністративних зборів і платежів, а також доходів від некомерційної господарської діяльності (49 видів), найменш - підгрупа власних надходжень бюджетних установ (два види: плата за послуги та інші джерела). Більше половини видів таких доходів належали тільки Державному бюджету України, чверть місцевим бюджетам. 19 видів неподаткових доходів отримували центральні та місцеві органи влади в якості спільного джерела бюджетних ресурсів.

Фактично, група неподаткових доходів включає всі обов'язкові платежі, суть яких не відповідає податкам, офіційним трансфертам, цільовим фондам і доходам від операцій 3 капіталом. Аналогічний підхід має місце і в міжнародній статистиці. У положеннях GFSM, 2014, де йдеться про інші надходження органів 
влади (розділ 5), досить часто використовуються формулювання на кшталт "інші, ніж".

Така ситуація цілком об'єктивна. Розвиток системи публічної влади як особливого суспільного інституту, виконання ㄲi структурними одиницями різних функцій супроводжується перерозподілом новоствореної вартості всілякими засобами, як наслідок акумулюванням переважної більшості отриманих доходів у бюджетному фонді. Підстави для такого перерозподілу відмітні, що й породжує труднощі із систематизацією доходів державного бюджету, зокрема й неподаткових доходів.

Застосувавши різні ознаки класифікації, науковці обгрунтували поділ неподаткових доходів на:

- приватноправові та публічноправові (правова природа платежів) [26];

- обов'язкові й добровільні (характер підстави для сплати) [13, с. 69; 25, с. 132];

- періодичні та разові (регулярність i стабільність надходжень) [25, с. 133];

- легко та складно передбачувані (розраховувані) (рівень достовірності планування) [25, с. 133];

- доходи бюджетів різних рівнів;

- доходи, які адмініструються різними органами влади [25, с. 134];

- надходження від господарської діяльності, від реалізації майнових прав, від адміністративно-регуляторної діяльності, від надання публічних послуг (джерело походження) [7, с. 65-66].

Саме до джерела походження як ознаки групування неподаткових доходів максимально наближена чинна в Україні бюджетна класифікація та положення GFSM, 2014.
Одночасне використання інших ознак дозволяє конкретизувати функціональне призначення великої кількості неподаткових доходів бюджетів, виявляючи тим різноманітні важелі впливу органів влади на соціально-економічні процеси та фінансово-господарську діяльність конкретних економічних суб'єктів.

Зважаючи на належність до цієї групи доходів бюджетів в Україні понад сотні видів платежів, серед основних функцій, що вони виконують, доцільно виокремити фіскальну, компенсаційну та регулюючу.

На відміну від податків, джерело яких, за твердженням А. Сміта, - це рента, прибуток, заробітна плата [33, с. 624], неподаткові доходи формуються за рахунок фонду, обсяг якого не зумовлює "народний дохід". Тому вони забезпечують органам державної влади певний рівень незалежності від результатів господарювання платників податків. Але за такого механізму перерозподілу вартості фіскальний тягар покладається нерівномірно, непропорційно на суб'єктів господарювання, домогосподарства та окремих осіб. 3 погляду останніх, така фіскальна дія неподаткових доходів економічно і соціально несправедлива. Проте суспільний інтерес дещо відмітний. Фіскальна функція неподаткових платежів сприяє формуванню частини доходів державного бюджету на відносно стабільній і прогнозованій основі. Відносно, тому що для неподаткових доходів, як і для будь-яких інших груп доходів бюджетів, характерні ризики справляння.

Так, протягом останніх років спостерігався щорічний позитивний приріст обсягу неподаткових доходів зведеного бюджету України, від $+10,4 \%$ до $+73,9 \%$ (таблиця 2).

Таблиця 2

Фактичні показники неподаткових доходів зведеного бюджету України за 2015-2020 роки

\begin{tabular}{|l|c|c|c|c|c|c|}
\hline \multicolumn{1}{|c|}{ Показник } & \multicolumn{5}{c|}{ Рік } \\
\cline { 2 - 7 } & 2015 & 2016 & 2017 & 2018 & 2019 & 2020 \\
\hline Усього доходів, млрд. грн. & 140,2 & 125,5 & 154,6 & 192,7 & 212,8 & 234,4 \\
\hline $\begin{array}{l}\text { Темп приросту, } \\
\text { \% до попереднього року }\end{array}$ & $+73,9$ & $-10,5$ & $+23,2$ & $+24,6$ & $+10,4$ & $+10,2$ \\
\hline Частка в доходах зведеного бюджету, \% & 21,5 & 16,0 & 15,2 & 16,3 & 16,5 & 17,0 \\
\hline Рівень виконання планових показників, \% & 108,1 & 96,1 & 97,7 & 96,1 & 105,4 & 94,3 \\
\hline $\begin{array}{l}\text { Частка неподаткових доходів зведеного бюджету, } \\
\text { яка надходить до Державного бюджету України, \% }\end{array}$ & 80,7 & 77,4 & 75,7 & 76,4 & 74,7 & 90,8 \\
\hline
\end{tabular}

*Джерело: розраховано за [32].

Винятком став 2016 рік, коли бюджети в Україні отримали на 14,7 млрд. грн. неподаткових доходів менше, ніж у попередньому році. Цей абсолютний показник зіграв головну роль у різкому зменшенні частки, яку займали неподаткові доходи в загальному обсязі доходів зведеного бюджету в 2016 році, на 5,5\% (до 16,0\%). Надалі розмір цього показника зріс до 17,0\%. 
Ще одним чинником відносного зменшення фіскальної ролі неподаткових доходів стало недовиконання планових показників їхнього збору. В 2016 він зменшився до 96,1\%. Натомість у 2015 і 2019 роках план 3 отримання неподаткових доходів перевиконано на $8,1 \%$ та $5,4 \%, \quad$ відповідно. Така результативність справляння неподаткових доходів, насамперед, важлива для центрального рівня державної влади в країні. Адже три чверті (в 2020 році - понад 90\%) їхнього загального обсягу надходило до Державного бюджету України.

На відміну від податкових надходжень, частка яких у доходах зведеного бюджету України в минулих роках була в межах $83,0 \%$ i темпи приросту яких щороку були позитивними, фіскальна роль неподаткових доходів суттєво нижча. Такий стан, разом 3 відсутністю "застосування інструментів фіскального тиску", дає окремим науковцям [15, с. 273] підстави вважати збалансування бюджетних показників основною метою справляння неподаткових надходжень. Наведену тезу проаналізуємо, порівнюючи розміри окремих груп доходів зведеного бюджету та його дефіциту з обсягом ВВП України (рисунок 1).

Справді, у 2016 році при відносному зростанні частки податкових надходжень на $1,8 \%$ ВВП відповідно чином (на 1,7\%) зменшилася фіскальна вага неподаткових доходів. Проте одночасно у відносному вимірі на $0,8 \%$ - збільшився розмір дефіциту зведеного бюджету України. У наступні роки позитивна динаміка відносного щодо ВВП розміру податкових надходжень супроводжувалася від'ємною зміною обсягу бюджетного дефіциту і навпаки. Так, 32017 року останній неухильно збільшувався, до 2,0\% ВВП у 2019 році. Натомість неподаткові доходи порівняно з ВВП перебували на рівні 5,2-5,6\%.

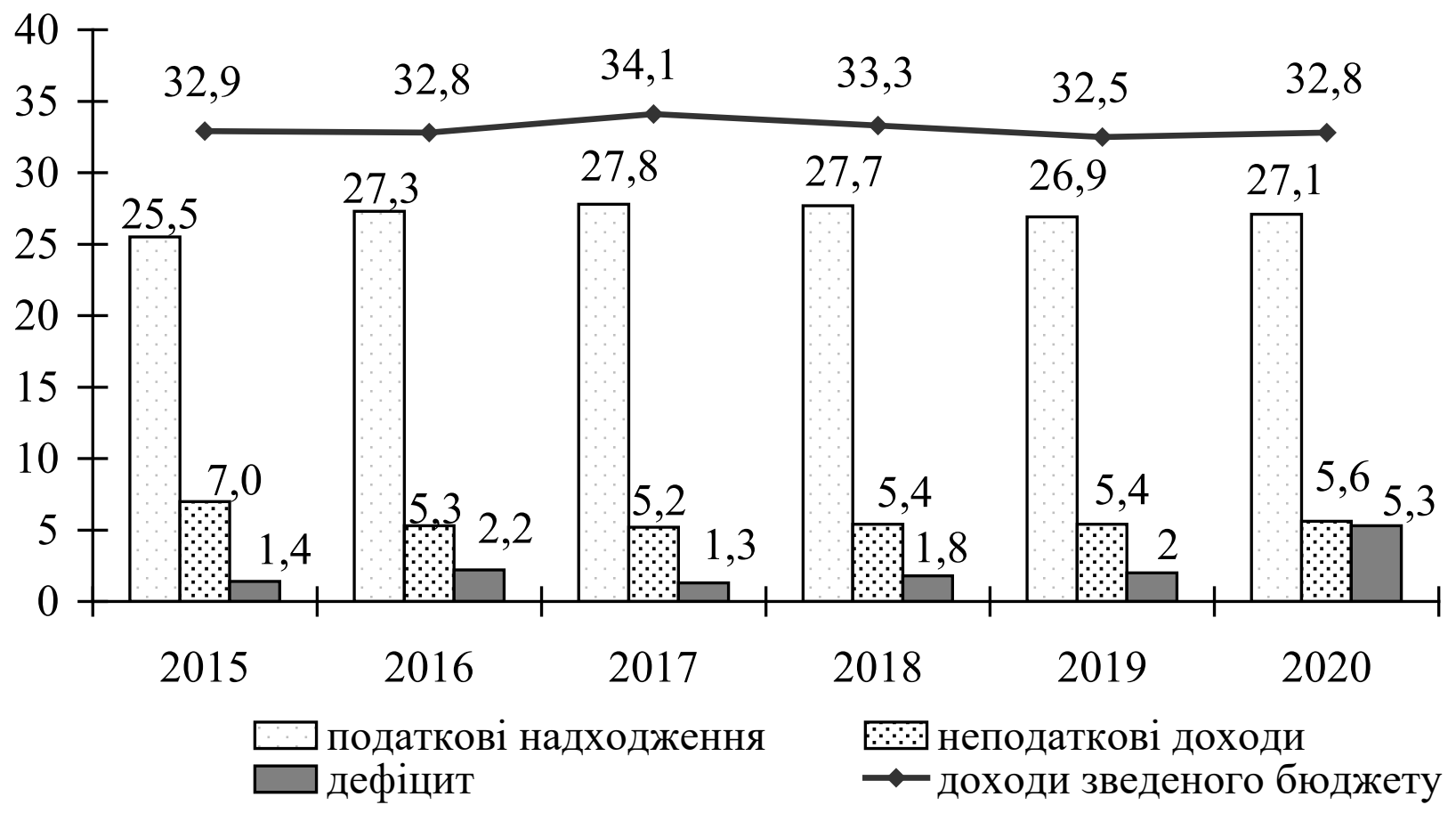

Рис. 1. Порівняння показників доходів і дефіциту зведеного бюджету України з обсягом ВВП за 2015-2020 роки, \% від ВВП

*Джерело: розраховано за [32].

Отже, 3 поглядом Дем'янишина В.Г. та Шаманської О.С. погоджуємося тільки частково, якщо йдеться в цілому про використання неподаткових, у тому числі позичкових, інструментів формування доходів бюджетів. Такий їхній фіскальний аспект об'єктивно посилюється в кризові для національної економіки періоди, останній з яких триває з 2020 року.

Компенсаційна функція неподаткових доходів, вважаємо, зумовлена природою їх справляння. 3 погляду загальносуспільного інтересу, отримання суб'єктами індивідуально вигідних благ i послуг від органів влади потребує хоча б часткової компенсації витрат. Ця функція властива багатьом видам неподаткових доходів, насамперед, окремим адміністративним зборам і платежам, іншим надходженням у складі доходів від власності та підприємницької діяльності, доходам від надання гарантій i операцій з кредитування тощо. 
Свій прояв компенсаційне призначення неподаткових доходів отримує в частковому їх зарахуванні до спеціального фонду бюджетів України. Так, протягом минулих років не менше третини неподаткових доходів зведеного бюджету мали цільове призначення. Для місцевих бюджетів цей показник суттєво вищий на рівні 73-75\%. Загалом неподаткові доходи формували більше половини обсягу спеціального фонду бюджетів в Україні. Тому рівень виконання їх планових показників, незважаючи на малу питому вагу в сукупних доходах бюджетів (див. табл. 2), залишається критично важливим для видатків, які мають спеціальне призначення, особливо в місцевих бюджетах.

Відплатний характер окремих видів неподаткових доходів наближає їх за змістом до ринкових інструментів перерозподілу вартості, зокрема до ціни. Тому повнота реалізації саме такого функціонального призначення неподаткових доходів бюджетів прямо залежить від розміру встановлених нормативів, тарифів, за якими вони справляються. На жаль, більшість із них непорівнянні (як у бік збільшення, так і в бік зменшення) 3 витратами, які несе держава при наданні індивідуально вигідних послуг. На проблему адекватності розміру ставок компенсаційних платежів у бюджет указували вітчизняні фахівці [34; 35]. Також вона стала однією з підстав для розробки законопроєкту про адміністративний збір [36]. Пропоновані ним положення, на наш погляд, варто відкоригувати, a саме: ставки неподаткових доходів доцільно визначати не в абсолютному розмірі $з$ наступним ïx періодичним переглядом, a відносно до традиційної бази (прожиткового мінімуму або мінімальної заробітної плати). На користь такої пропозиції - багаторічний вітчизняний досвід справляння окремих видів доходів державного бюджету (насамперед, плати за цільове використання природних ресурсів) за фіксованими ставками, перегляд розміру яких 3 різних причин відбувався несвоєчасно.

Також вважаємо доцільною відмову від застосування неоподатковуваного мінімуму доходів громадян (НМДГ) як відносної бази для розрахунку ставки неподаткових доходів, яким властивий компенсаційний характер. 3 одного боку, цей показник формально забезпечує відносну базу справляння обов'язкових платежів у бюджет. Але 3 іншого, - зважаючи на незмінність абсолютного розміру НМДГ з 1996 року, фактично він перетворився на фіксовану величину, яка в умовах поступового знецінення національної грошової одиниці потребує перегляду.
Через справляння неподаткових доходів (які $\epsilon$ фактичними витратами тих чи інших економічних одиниць) органи влади отримують можливість впливати на ухвалення їхніх рішень, корегувати, насамперед, девіантну поведінку суб'єктів, зрештою, регулювати процеси руху вартості відповідно до встановлених соціальних і економічних орієнтирів. Тобто особливість мети застосування неподаткових доходів полягає в досягненні публічних цілей, які сьогодні забезпечують отримання конкретних соціальноекономічних ефектів [12, с. 5].

Загалом серед основних напрямків впливу неподаткових доходів бюджетів на економічні процеси в країні науковці [18] виокремили:

1) забезпечення економічного зростання шляхом:

- прискорення розвитку базових галузей національної економіки;

• сприяння швидкому розвитку освіти;

• компенсації ринкових недосконалостей i стандартизації ринкових замовлень;

- поліпшення споживчої ефективності функціонування державних (публічних) інституцій і оптимізації динамічного розміщення (алокаціі) ресурсів;

2) перешкоджання економічному зростанню через:

- посилення фінансового тиску на підприємства та ускладнення формування капіталу (відмітимо, що за "принципом доміно" ці ж фінансові труднощі перекладаються на споживачів, зрештою, на населення як базового споживача);

- заохочення місцевих органів влади до неефективного будівництва та спотворення територіальної промислової інфраструктури;

• порушення механізму функціонування ринку.

Крім того, окремі види й форми неподаткових доходів сприяють погіршенню якості державного управління, оскільки посилюють роз'єднаність інтересів влади і громадян, сприяють розвитку корупції, протекціонізму, загострюють ризик конфліктів $[5 ; 37]$.

Оцінка вітчизняних реалій регулятивного впливу неподаткових доходів на економічне зростання потребує глибшого вивчення та аналізу, що визначає напрямки подальшого дослідження. Але вже зараз можна наголосити на потенціалі цілеспрямованого регулювання фінансової поведінки економічних суб'єктів, який закладений застосуванням доходів від власності у формі частини чистого прибутку або 
дивідендів, що надходять у Державний бюджет України та місцеві бюджети як результат функціонування підприємств 3 державною чи комунальною часткою власності. Їхній зміст, сучасний порядок застосування та адміністрування подібний до податку на прибуток підприємств. Це дозволяє вести мову про використання окремих елементів механізму відрахувань 3 прибутку (нормативу, порядку розрахунку бази, терміну сплати) як інструментів впливу. Проте саме щодо них не дотримується базовий принцип справляння обов'язкових платежів у бюджет - стабільність і передбачуваність фінансових відносин держави 3 економічними суб'єктами. У минулому в процесі формування таких доходів бюджетів постійно коригувалися прогнозні показники фінансових результатів підприємств, їхні фінансові плани затверджувалися несвоєчасно [38, с. 24-25], а нормативи відрахувань 3 прибутку змінювалися щороку. Їхнє зменшення дозволяє розширити внутрішню базу фінансування державних i комунальних підприємств. Але, на жаль, до цього часу органи державної влади та місцевого самоврядування не здійснюють ефективний контроль за цільовим використанням вивільнених коштів, їх спрямуванням на потреби розвитку таких економічних одиниць.

Вилучення значної частини прибутку державних i комунальних підприємств, яке відбувається щорічно на нестабільній, малопрогнозованій основі в директивному порядку, веде до зменшення внутрішнього фінансового потенціалу розвитку таких суб'єктів, з одного боку, а з іншого - до збільшення доходів бюджету в поточному році. Зауважимо, що доходи від власності та підприємницької діяльності за показником частки в неподаткових доходах зведеного бюджету України з 2016 року мали тренд до зростання (від 42,5\% до 51,5\% у 2020 році). Одночасно збільшувалася сукупна питома вага відрахувань 3 прибутку й дивідендів, які сплачувалися до бюджетів (з 22,9\% до 30,2\%, відповідно). Такі дані дозволяють вести мову про вагомість орієнтиру органів державної влади на досягнення короткострокових фіскальних цілей. Він, на додачу до інших чинників [39], перешкоджає платникам подібних дивідендів отримати економічний ефект. Утім, на довгострокову перспективу мінімізація забезпечення публічного інтересу закладається також. Тому вважаємо, що подібна кореляція потребує від органів державної влади та місцевого самоврядування конкретизації пріоритетів власної фінансової політики, здійснення обгрунтованого вибору між їі цілями коротко- чи довгострокового характеру.
Вилучення частини заробленого доходу на користь центрального бюджету країни відбувається i щодо Національного банку України. Проте в цьому випадку, на наш погляд, жодного регулюючого ефекту не спостерігається. Такий захід передбачено Законом України "Про Національний банк України" [40, стаття $\left.5^{1}\right]$, щорічними законами про Державний бюджет, а також Меморандумом про економічну та фінансову політику, яким доповнено Лист про наміри співпраці Українського уряду 3 Міжнародним валютним фондом [41, с. 32]. Натомість $є$ підстави вести мову про фіскальне призначення такого виду доходів державного бюджету, особливо, якщо взяти до уваги терміни виконання відповідного фінансового зобов'язання НБУ. Активація різноманітних ризиків формування дохідної частини бюджетів неодноразово призводила до необхідності спрямувати в Державний бюджет України більшу частину річної суми прибутку до розподілу НБУ в першому півріччі, а не рівномірно протягом бюджетного періоду.

Певний регулюючий ефект, але іншого спрямування, спостерігався щодо частини неподаткових доходів, які органи місцевого самоврядування отримували у формі плати за розміщення тимчасово вільних коштів бюджету. При цьому їм вдалося досить ефективно оперувати тимчасово вільними бюджетними ресурсами та співпрацювати 3 банківськими установами. За депозитами суб'єктів сектору загального державного управління (СЗДУ) з 2011 року (часу ухвалення відповідної постанови Кабінету Міністрів України [42]) банки сплачували, як правило, вищий дохід, ніж іншим вкладникам (рисунок 2). Тільки в 2014, 2015 i 2018 роках середньозважена депозитна ставка в цілому по секторах національної економіки незначно переважила відповідний еквівалент для інститутів СЗДУ.

Отримавши можливість діяти економічно вигідно, управлінським структурам на місцевому рівні в 2020 році вдалося отримати 3 указаного джерела 931,1 млн. грн., або ж 59\% усього обсягу доходів від власності та підприємницької діяльності (для порівняння: в 2015 році ці ж показники становили 127,0 млн. грн. і 26\%, відповідно).

Аналогічно, незважаючи на статус бюджетних установ, потенційна можливість заробити є і в розпорядників бюджетних коштів. Вона регулюється статтею 13 Бюджетного кодексу України та передбачає надання послуг, ведення господарської діяльності, реалізацію цільових заходів, передачу в оренду майнових активів, отримання фінансових допомог тощо. 
Природно, така діяльність, крім іншого, передбачає проактивну позицію керівництва бюджетних установ, у тому числі використання ними дієвих заходів стимулювання працівників до більшої результативності власної роботи. Такий підхід знайшов своє втілення, насамперед, у діяльності вітчизняних закладів вищої освіти. Їхній розмір фінансування по спеціальному фонду кошторисів (де-факто, власні надходження) досяг третини всього обсягу бюджетного фінансування.

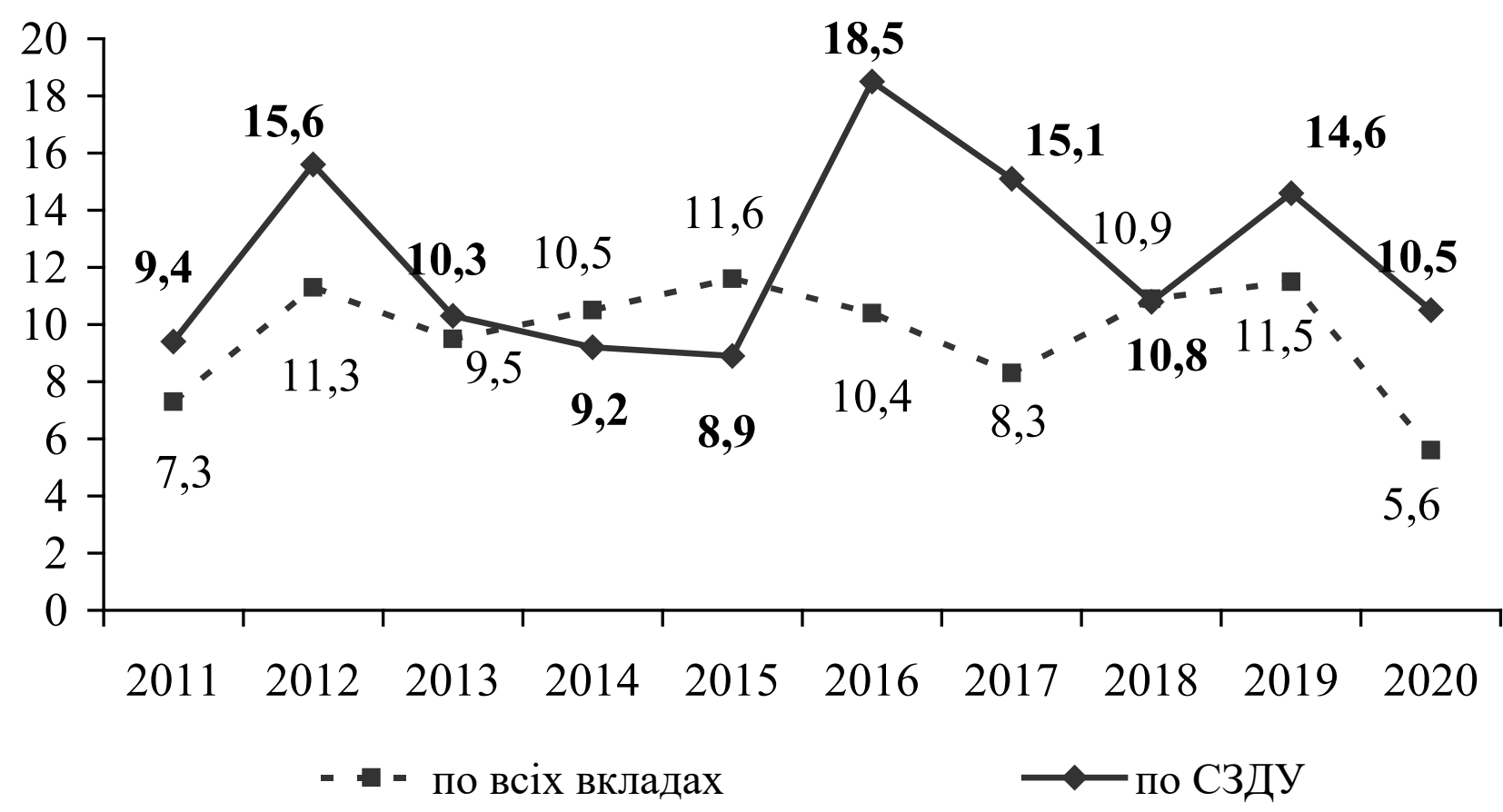

\section{Рис. 2. Середньозважені процентні ставки по нових депозитах резидентів України за 2011-2020 роки, \% [43]}

Загалом власні надходження бюджетних установ складали чверть неподаткових доходів Державного бюджету України та не менше двох третин - місцевих бюджетів, що вказує на їхній вагомий фіскальний ефект. 3 іншого боку, відповідні плани з урахуванням змін, унесених розпорядниками бюджетних коштів, щорічно недовиконувалися, в середньому на понад $10 \%$. Серед імовірних чинників, які зумовили такий стан, виділимо такі:

- недостатньо ефективне управління майном, здійснюване розпорядниками бюджетних коштів;

- невідповідність вартості оренди майнових активів бюджетних установ, а також послуг, які надаються ними на платній основі, ринковому рівню цін;

- недостатня ініціативність розпорядників бюджетних коштів щодо виявлення додаткових (цільових) джерел фінансування;

- низькорезультативне обгрунтування планів 3 формування установами власних надходжень.

Відповідно, резерви зростання обсягу власних надходжень бюджетних установ вбачаємо в подоланні негативного впливу таких чинників.

Висновки. Кризові умови функціонування національної економіки актуалізують пошук резервів поліпшення механізму фінансового забезпечення процесу задоволення суспільних потреб. Окремі 3 них лежать у площині підвищення ефективності справляння неподаткових доходів бюджетів.

Функціональне призначення різних доходів бюджетів випливає з їхньої суті, яка, вважаємо, повинна чітко й однозначно відображатися в назві. Тому пропонуємо перейменувати другу групу доходів бюджетів в Україні на "неподаткові доходи". Змістове ii наповнення повинно відповідати міжнародним обліковим стандартам. Це зумовлює необхідність змінити вітчизняну бюджетну класифікацію доходів.

Значна видова різноманітність неподаткових доходів бюджетів в Україні відображає великі масштаби регуляторної діяльності органів державної влади та місцевого самоврядування. Тому можливості iï оптимізації пов'язуємо 3 обгрунтованим упорядкуванням напрямків 
впливу держави як владного інституту на суспільні процеси.

Дослідження функціонального призначення неподаткових доходів бюджетів в Україні дає підстави виокремлювати кілька його аспектів: фіскальний, компенсаційний i регулюючий. Оцінка результативності їх акумулювання органами державної влади та місцевого самоврядування дозволяє констатувати домінування фіскального призначення неподаткових доходів. Його активізація надалі неможлива без урахування контроверсійності фінансових інтересів платників і бенефіціарів неподаткових доходів бюджетів.

Компенсаційне призначення неподаткових доходів особливо вагоме для органів місцевого самоврядування, в бюджетах яких три чверті обсягу спеціального фонду акумулюється за допомогою таких інструментів. Його оптимізацію варто розпочати із законодавчих змін окремих елементів механізму справляння неподаткових доходів, зокрема, бази і ставок.

Неподаткові доходи також використовують для отримання соціально-економічних ефектів публічного характеру. Тому їхнє регулююче призначення доцільно нарощувати, забезпечуючи: 1) прогнозованість фінансових взаємовідносин органів влади 3 державними та комунальними підприємствами й організаціями, високоефективний менеджмент їх функціонування, а також узгодженість цілей тактики i стратегії державної фінансової політики на мікро- й макроекономічному рівнях; 2) конкурентний рівень управління активами 3 боку розпорядників бюджетних коштів; 3) стимулювання ініціативності та відповідального виконання функціональних обов'язків суб'єктами, які адмініструють надходження неподаткових доходів у Державний бюджет України і місцеві бюджети.

\section{Список літератури}

1. Про затвердження Методики оцінювання фіскальних ризиків : постанова Кабінету Міністрів України від 24 квіт. 2019 р. № 351. URL: https://zakon.rada.gov.ua/laws/show/351-2019-

$\% \mathrm{D} 0 \% \mathrm{BF}$ Техt (дата звернення: 11.01.2021).

2. Іваницька О.М., Кощук Т.В. Управління фіскальними ризиками в умовах пандемії COVID-19. Фінанси України. 2020. № 7. С. 47-61. DOI: 10.33763/finukr2020.07.047

3. Оперативна інформація про видатки на боротьбу з COVID-19. Рахункова палата Украйни : веб-сайт.

URL:

https://public.tableau.com/views/COVID-

19UKRAINE/sheet0?:language $=$ en $\&$ : display_count $=\mathrm{y} \& \mathrm{p}$ ublish $=$ yes\&:origin $=$ viz share link\&fbclid $=$ IwAR052v5c AdZcgBqHElO4zmrgRP9K1-

8GvScOpAxC8mKVaKWWG98oJwuDAuI\&:showVizH ome $=$ no (дата звернення: 11.01.2021).

4. Tax Policy for Inclusive Growth after the Pandemic / Ruud de Mooij та ін., IMF, Dec. 16, 2020; Tax Issues: An Overview / IMF, Apr. 6, 2020. URL: https://www.imf.org/en/Publications/SPROLLs/covid19special-notes\#fiscal (accessed: 11.01.2021).

5. Total consolidated transactions. European Central Bank : веб-сайт. URL: https://sdw.ecb.europa.eu/browse.do?node $=9693791$ (accessed: 11.01.2021).

6. Prichard W., Salardi P., Segal P. Taxation, non-tax revenue and democracy: New evidence using new crosscountry data. World Development. 2018. Vol. 109, September. P. 295-312. DOI: 10.1016/j.worlddev.2018.05.014. URL: https://www.sciencedirect.com/science/article/pii/S03057 50X18301621 (accessed: 11.01.2021).

7. Горин В. Теоретичні засади неподаткових надходжень бюджету. Свim фінансів. 2015. Вип. 1. С. 58-68.
8. Дем'янишин В.Г. Теоретична концептуалізація і практична реалізація бюджетної доктрини України : монографія. Тернопіль : ТНЕУ, 2008. 496 с.

9. Касперович Ю. Формування неподаткових надходжень бюджету в системі фінансовоекономічного регулювання. Економічний часопис-XXI. 2013. № 9-10(2). С. 55-58.

10. Огонь Ц.Г. Доходи бюджету України: теорія і практика : монографія. Київ : Київ. нац. торг.-економ. ун-т, 2003. $580 \mathrm{c.}$

11. Левкович В. Поняття i правова природа неподаткових надходжень. Фінанси Украӥни. 2009. № 10. С. 38-42.

12. Маринчак Є.С. Наукові погляди на сутність правового явища "обов'язкові неподаткові платежі". Державне управління та адміністрування, сфера обслуговування, економіка та міжнародні відносини як рушійні сили економічного зростання держав XXI століття. Вид. 1. Вінниця, 2020. С. 2-15.

13. Якимчук Н. Фіскальні неподаткові платежі до бюджетів: проблеми правового змісту та правового регулювання. Публічне право. 2014. № 1. С. 68-76.

14. Богдан I.В., Коноваленко Д.В., Яра Т.Ю. Класифікація доходів сектору загальнодержавного управління України згідно 3 GFSM 2014. Фінанси України. 2017. № 8. С. 33-57.

15. Дем'янишин В.Г., Шаманська О.С. Неподаткові надходження: проблеми та роль у доходах бюджету держави. Фінансово-кредитна діяльність: проблеми теорії та практики. 2011. Вип. 2. С. 268-274.

16. Петраков Я.В. Еволюція парадигми використання неподаткових бюджетних доходів як інструменту мобілізації фінансових ресурсів до державного бюджету. Вісник ЧДТУ. Сер. «Економічні науки». Чернігів : ЧДТУ, 2010. № 43. С. 209-217.

17. Письменний В.В. Неподаткові джерела формування доходів місцевих бюджетів України. Галииьький економічний вісник. 2013. № 1. С. 101-106. 
18. Wang Q., Wang Z. Empirical analysis of the impact of government non-tax revenue on economic growth. Contemporary finance, 2009, № 12, p. 30-35; Wang, Q. Research on the relationship between government non-tax revenue and economic growth. Beijing : Science Press, 2011.

19. Zhang S., Huang Z. Research on perfecting government non-tax revenue management system. Open journal of accounting. 2019. Vol. 8, № 3. DOI: $10.4236 /$ ojact.2019.83003. URL: https://www.scirp.org/journal/paperinformation.aspx?pap erid=94073 (accessed: 12.01.2021).

20. Yamin N.Yu., Amir A.M., Aygraini M. The management of non-tax revenue: an evaluative review. Advances in social science, education and humanities research : 5th International conference on community development (AMCA 2018). Vol. 231, p. 432-435. DOI: $10.2991 /$ amca-18.2018.119.

URL: https://www.researchgate.net/publication/327900969_The Management_of_Non-

Tax_Revenue_An_Evaluative_Review 12.01.2021).

(accessed:

21. Mourre G., Reut A. Non-tax revenue in the European Union: A source of fiscal risk? Discussion paper 044. February 2017. URL: https://ec.europa.eu/info/sites/info/files/dp044_en_0.pdf (accessed: 12.01.2021).

22. Morales-Contreras M.F., Triguero Á., Riera I.R. Non-tax revenue for the State. The case of Spain. URL: https://repositorio.comillas.edu/rest/bitstreams/203499/ret rieve (accessed: 12.01.2021).

23. Purohit M.C., Purohit V.K. Mobilising non-tax revenue: an empirical analysis of trends in States. Economic and political weekly. 2009. Vol. 44, №. 5, p. 54-62. URL: https://www.jstor.org/stable/40278460 (accessed: 12.01.2021).

24. Батяева А.P. Неналоговые доходы государственного бюджета Российской Федерации : автореф. дисс... на соискание науч. степени канд. юр. наук : спец. 12.00.14. Москва, 2008. 25 с.

25. Ярцева И.Ю. Формирование неналоговых доходов как источника развития муниципальных образований : автореф. дисс... на соискание науч. степени канд. эк. наук : спец. 08.00.10. Томск, 2011. $25 \mathrm{c}$.

26. Карасев В.А. Финансово-правовое регулирование неналоговых доходов государственного бюджета Российской Федерации : автореф. дисс... на соискание науч. степени канд. юр. наук : спец. 12.00.14. Москва, 2004. 25 с.

27. Иванов Б.Н. О системе советского финансового права. ВЮЗИ. Труды. Т. ІХ. Москва, 1967.

28. Seligman E.R.A. The Classification of Public Revenues. The Quarterly Journal of Economics, Vol. 7, Is. 3, April 1893, p. 286-321. DOI: 10.2307/1884005. URL: https://academic.oup.com/qje/articleabstract/7/3/286/1826687?redirectedFrom=fulltext (accessed: 12.01.2021). URL:

29. Government Finance Stastistics Manual, 2014.

https://www.imf.org/external/Pubs/FT/GFS/Manual/2014/ gfsfinal.pdf (accessed: 14.01.2021).
30. The European System of Accounts. URL: https://ec.europa.eu/eurostat/documents/3859598/592569 3/KS-02-13-269-EN.PDF/44cd9d01-bc64-40e5-bd40d17df0c69334 (accessed: 14.01.2021).

31. Бюджетний кодекс України : Закон України від 8 лип. 2010 p. № 2456-VI. URL: https://zakon.rada.gov.ua/laws/show/2456-17\#Text (дата звернення: 14.01.2021).

32. Звітність. Державна казначейська служба України : веб-сайт. URL: http:/www.treasury.gov.ua/ (дата звернення: 26.03.2021).

33. Сміт А. Дослідження про природу і причини багатства народів / пер. 3 англ. О. Васильєв, М. Межевікіна, А. Малівський. Київ : Наш формат, 2018. $736 \mathrm{c.}$

34. Якимчук Н.Я. Правовий режим обов'язкових платежів в Україні: конституційно-правові засади та проблеми реформування. Право України. 2012. № 1-2. С. $122-132$.

35. Тимощук В. На шляху до прозорих та обгрунтованих платежів за адміністративні послуги. Децентралізація дає можливості : веб-сайт. URL: https://decentralization.gov.ua/news/columns/13018 (дата звернення: 18.01.2021).

36. Про адміністративний збір : проєкт Закону від 16 лист. 2020 p. № 4380. URL: http://w1.c1.rada.gov.ua/pls/zweb2/webproc4_1?id=\&pf3 $511=70434$ (дата звернення: 27.01.2021).

37. Ross M. What have we learned about the resource curse? Annual review of political science. 2015. № 18. P. 239-259. DOI: 10.1146/annurev-polisci-052213-040359. URL:

https://www.sscnet.ucla.edu/polisci/faculty/ross/papers/art icles/Ross $\% 20$ -

$\%$ 20What $\% 20$ have $\% 20 \mathrm{we} \% 20$ learned $\% 20$ ARPS $\% 20201$ 5.pdf (accessed: 27.01.2021).

38. Звіт про результати аудиту ефективності планування i прогнозування неподаткових надходжень до державного бюджету. Рахункова палата України : веб-сайт. URL: https://rp.gov.ua/upload-

files/Activity/Collegium/2019/14-4_2019/Zvit_144_2019.pdf (дата звернення: 27.01.2021).

39. Махінчук В.M., Данчул О.С. Причини неефективного функціонування підприємств державної форми власності. Науковий вісник Львівського державного університету внутрішніх справ. 2018. № 1. C. 72-80. URL: https://www.lvduvs.edu.ua/documents_pdf/visnyky/nvsy/ 01_2018/11.pdf; Лоневський О. Комунальні підприємства - хронічна проблема країни. Як це змінити. Центр економічної стратегї : веб-сайт. URL: https://ces.org.ua/utility-companies-4/ (дата звернення: 28.01.2021).

40.Про Національний банк України : Закон України від 20 трав. 1999 р. № 679-XIV. URL: https://zakon.rada.gov.ua/laws/show/679-14\#n84 (дата звернення: 28.01.2021).

41. Меморандум про економічну та фінансову політику від 2 червня 2020 року. Міністерство фінансів Украӥни : веб-сайт. URL: https://mof.gov.ua/uk/memorandum_of_economic_and_fi 
nancial policies by the authorities of ukraine- 435 (дата звернення: 28.01.2021).

42. Про затвердження Порядку розміщення тимчасово вільних коштів місцевих бюджетів на вкладних (депозитних) рахунках у банках : постанова Кабінету Міністрів України від 12 січ. 2011 р. № 6.
URL: $\quad$ https://zakon.rada.gov.ua/laws/show/6-2011\%D0\%BF\#Text (дата звернення: 28.01.2021).

43. Процентні ставки за кредитами та депозитами. Цінні папери резидентів. Індекс ПФТС. Національний банк України : веб-сайт. URL: https://bank.gov.ua/ua/statistic/sector-financial/datasector-financial\#1ms (дата звернення: 28.02.2021).

\section{References}

1. Resolution of the Cabinet of Ministers of Ukraine "On approval of the Methodology for assessing fiscal risks", dated 24 April 2019, no. 351. URL: https://zakon.rada.gov.ua/laws/show/351-2019-

$\%$ D0\%BF\#Text (accessed: 11.01.2021).

2. Ivanytska, O.M., Koschuk, T.V. (2020) "Fiscal risk management in conditions of the COVID-19 pandemic", Finansy Ukrainy, no. 7, pp. 47-61.

3. Operational information on expenditures to combat COVID-19. The Accounting Chamber of Ukraine. URL: https://public.tableau.com/views/COVID-

19UKRAINE/sheet0?:language $=$ en $\&$ :display_count $=\mathrm{y} \& \mathrm{p}$ ublish=yes\&:origin $=$ viz_share_link\&fbclid $=$ IwAR052v5c AdZcgBqHElO4zmrgRP9K1-

8GvScOpAxC8mKVaKWWG98oJwuDAuI\&:showVizH ome $=$ no (accessed: 11.01.2021).

4. Ruud de Mooij etc. (2020), Tax Policy for Inclusive Growth after the Pandemic, IMF, Dec. 16; Tax Issues: An Overview, IMF, Apr. 6, 2020. URL: https://www.imf.org/en/Publications/SPROLLs/covid19special-notes\#fiscal (accessed: 11.01.2021).

5. Total consolidated transactions. European Central Bank. URL:

https://sdw.ecb.europa.eu/browse.do?node $=9693791$ (accessed: 11.01.2021).

6. Prichard, W., Salardi, P., Segal, P. (2018), Taxation, non-tax revenue and democracy: New evidence using new cross-country data. World Development, Vol. 109, September, pp. 295-312. DOI: 10.1016/j.worlddev.2018.05.014. URL: https://www.sciencedirect.com/science/article/pii/S03057 50X18301621 (accessed: 11.01.2021).

7. Goryn, V. (2015), "Theoretical aspects of non-tax revenues", World of Finance, no. 1, pp. 56-68.

8. Demyianyshyn, B.H. (2008), Teoretychna kontseptualizatsiia $i$ praktychna realizatsiia biudzhetnoii doktryny Ukrainy [Theoretical conceptualization and practical implementation of the budget doctrine of Ukraine], TNEU, Ternopil, Ukraine.

9. Kasperovych, Yu. (2013), "Non-tax budget revenues in financial and economic regulation system", Economic Annals-XXI, vol. 9-10, no. 2, pp. 55-58.

10. Ohon, Ts.H. (2003), Dokhody biudzhetu Ukrainy: teoriia $i$ praktyka [Budget revenues of Ukraine: theory and practice], Kyiv. nats. torh.-ekon. un-t, Kyiv.

11. Levkovych, V. (2009), "Concept and legal nature of non-tax revenues", Finansy Ukrainy, no. 10, pp. 38-42.

12. Marynchak, Ye.S. (2020), "Scientific views on the essence of the legal phenomenon "mandatory non-tax payments", in Derzhavne upravlinnia ta administruvannia, cfera obsluhovuvannia, ekonomika ta mizhnarodni vidnosyny yak rushiini syly ekonpmichnoho zrostannia derzhav XXI stolittia [Public administration, services, economics and international relations as driving forces of economic growth of the XXI century], no. 1, Vinnytsia, Ukraine, pp. 2-15.

13. Yakymchuk, N. (2014), "Fiscal non-tax payments to budgets: problems of legal content and legal regulation", Public law, no. 1, pp. 68-76.

14. Bohdan, I.V., Konovalenko, D.V., Yara, T.Yu. (2017), "Classification of Ukraine's general government sector's revenue according to GFSM 2014", Finansy Ukrainy, no. 8, pp. 33-57.

15. Demyianyshyn, B.H., Shamanska, O.S. (2011), "Non-tax revenues: problems and role in the state budget revenues", Finansovo-kredytna diialnist: problemy teorii ta praktyky, no. 2, pp. 268-274.

16. Petrakov, Ya.B. (2010), "Evolution of paradigm using non-tax budget revenues as a tool for mobilizing financial resources to the state budget", Visnyk ChDTU, Ser. "Ekonomichni nauky", no. 43, pp. 209-217.

17. Pysmennyi, V.V (2013), "Non-tax sources of local budgets' revenues forming in Ukraine", Halytskyi ekonomichnyi visnyk, no. 1, pp. 101-106.

18. Wang, Q., Wang, Z. (2009), "Empirical analysis of the impact of government non-tax revenue on economic growth". Contemporary finance, no. 12, pp. 30-35; Wang, Q. (2011), Research on the relationship between government non-tax revenue and economic growth, Science Press, Beijing.

19. Zhang, S., Huang, Z. (2019), "Research on perfecting government non-tax revenue management system", Open journal of accounting. vol. 8, no 3. DOI: $10.4236 /$ ojact.2019.83003. URL: https://www.scirp.org/journal/paperinformation.aspx?pap erid=94073 (accessed: 12.01.2021).

20. Yamin, N.Yu., Amir, A.M., Aygraini, M. (2018), "The management of non-tax revenue: an evaluative review", Advances in social science, education and humanities research, 5th International conference on community development, vol. 231, pp. 432-435. DOI: 10.2991/amca-18.2018.119. URL: https://www.researchgate.net/publication/327900969_The Management_of_Non-

Tax_Revenue_An_Evaluative_Review (accessed: 12.01.2021).

21. Mourre, G., Reut, A. (2017), "Non-tax revenue in the European Union: a source of fiscal risk?", Discussion paper $044 . \quad$ URL: https://ec.europa.eu/info/sites/info/files/dp044_en_0.pdf (accessed: 12.01.2021).

22. Morales-Contreras, M.F., Triguero, Á., Riera, I.R. (2019), "Non-tax revenue for the state. The case of Spain".

URL: https://repositorio.comillas.edu/rest/bitstreams/203499/ret rieve (accessed: 12.01.2021). 
23. Purohit, M.C., Puro, V.K. (2009), "Mobilising nontax revenue: an empirical analysis of trends in States", Economic and political weekly, vol. 44, no. 5, pp. 54-62. URL: https://www.jstor.org/stable/40278460 (accessed: 12.01.2021).

24. Batiaieva, A.R. (2008), "Non-tax revenues of the state budget in the Russian Federation", Abstract of Ph.D. dissertation, law sciences, 12.00.14, People's Friendship University of Russia, Moscow, Russia.

25. Yartseva, I.Yu. (2011), "Forming of non-tax revenues as source of development of municipalities", Abstract of Ph.D. dissertation, economic sciences, 08.00.10, Tomsk, Russia.

26. Karasev, V.A. (2004), "Financial-legal regulation of non-tax revenues of the state budget in the Russian Federation", Abstract of Ph.D. dissertation, law sciences, 12.00.14, Moscow, Russia.

27. Ivanov, B.N. (1967), O sisteme sovetskoho finansovogo prava [About the system of soviet financial law], VYuSI, Trudy, vol. IX, Moscow.

28. Seligman, E.R.A. (1893), The classification of public revenues. The quarterly journal of economics, vol. 7, is. 3, pp. 286-321. DOI: 10.2307/1884005. URL: https://academic.oup.com/qje/article-

abstract/7/3/286/1826687?redirectedFrom=fulltext (accessed: 12.01.2021).

29. Government Finance Stastistics Manual (2014). URL:

https://www.imf.org/external/Pubs/FT/GFS/Manual/2014/ gfsfinal.pdf (accessed: 14.01.2021).

30. The European System of Accounts. URL: https://ec.europa.eu/eurostat/documents/3859598/592569 3/KS-02-13-269-EN.PDF/44cd9d01-bc64-40e5-bd40d17df0c69334 (accessed: 14.01.2021).

31. Law of Ukraine "Budget Code of Ukraine", dated 8 July 2010, no. 2456-VI. URL: https://zakon.rada.gov.ua/laws/show/2456-17\#Text (accessed: 14.01.2021).

32. Reporting, State Treasure Service of Ukraine. URL: http://www.treasury.gov.ua/ (accessed: 26.03.2021).

33. Smit, A. (2018), Doslidzhennia pro pryrodu $i$ prychyny bahatstva narodiv [An inquiry into the nature and causes of the wealth of nations], Translated by Vasyliev, O., Mezhevikina, M., Malivskyi, A., Nash format, Kyiv, Ukraine.

34. Yakymchuk, N.Ya. (2012), "Legal regime of mandatory payments in Ukraine: constitutional and legal bases and problems of the reforming", Law of Ukraine, no. 1-2, pp. 122-132.

35. Tymoshchuk, V. "On the way to the transparent and reasonable payments for administrative services",
Decentralization provides opportunities. URL: https://decentralization.gov.ua/news/columns/13018 (accessed: 18.01.2021).

36. The draft law "On administrative fees", dated 16 November 2020, no. 4380. URL: http://w1.c1.rada.gov.ua/pls/zweb2/webproc4_1?id=\&pf3 511=70434 (accessed: 27.01.2021).

37. Ross, M. (2015), "What have we learned about the resource curse?", Annual review of political science, no. 18, pp. 239-259. DOI: 10.1146/annurev-polisci-052213040359 .

URL: https://www.sscnet.ucla.edu/polisci/faculty/ross/papers/art icles/Ross $\% 20$ -

$\% 20$ What $\% 20$ have $\% 20$ we $\%$ 20learned $\% 20$ ARPS $\% 20201$ 5.pdf (accessed: 27.01.2021).

38. Report on the results of the audit of the effectiveness of planning and forecasting of non-tax revenues to the state budget, The Accounting Chamber of Ukraine. URL: https://rp.gov.ua/uploadfiles/Activity/Collegium/2019/14-4_2019/Zvit_14-

4_2019.pdf (accessed: 27.01.2021).

39. Makhinchuk, V.M., Danchul, O.S. (2018), "Causes of the inefficient functioning of state-owned enterprises", Naukovyi visnyk Lvivskoho derzhavnoho universytetu vnutrishnikh sprav, no. 1, pp. 72-80 URL: https://www.lvduvs.edu.ua/documents_pdf/visnyky/nvsy/ 01_2018/11.pdf; Lonevskyi, O. "Utilities are a chronic problem in the country. How to change it?", Centre of Economic Strategy. URL: https://ces.org.ua/utilitycompanies-4/ (accessed: 28.01.2021).

40. Law of Ukraine "On the National Bank of Ukraine", dated 20 May 1999, no. 679-XIV. URL: https://zakon.rada.gov.ua/laws/show/679-14\#n84 (accessed: 28.01.2021).

41. Memorandum on Economic and Financial Policy, dated 2 June 2020, Ministry of Finance of Ukraine. URL: https://mof.gov.ua/uk/memorandum_of_economic_and_fi nancial_policies_by_the_authorities_of_ukraine-435 (accessed: 28.01.2021).

42. Resolution of the Cabinet of Ministers of Ukraine "About the statement of the Order of placement of temporarily free means of local budgets on deposit accounts in banks", dated 12 January 2011, no. 6. URL: https://zakon.rada.gov.ua/laws/show/6-2011-

$\%$ D0\%BF\#Text (accessed: 28.01.2021).

43. Interested rates on loans and deposits. Residents' securities. Stock exchange PFTS index, National Bank of Ukraine. URL: https://bank.gov.ua/ua/statistic/sectorfinancial/data-sector-financial\#1 $\mathrm{ms}$ 28.02.2021) 


\section{ФУНКЦИОНАЛЬНОЕ НАЗНАЧЕНИЕ НЕНАЛОГОВЫХ ДОХОДОВ БЮДЖЕТОВ КАК ПРОЯВЛЕНИЕ ИХ СУТИ, ВОЗМОЖНОСТИ ЕГО АКТИВИЗАЦИИ В УКРАИНЕ}

Обоснована необходимость изменить название второй группь доходов государственного бюджета Украины на "неналоговые доходы" и упорядочить ее состав соответственно с международными стандартами. Проанализировано функииональное назначение неналоговых доходов и выявлено доминирование их фискальной функции. Отмечено, что дальнейтая ее активизация возможна при условии согласования финансовых интересов государства и плательщиков. Компенсационное назначение неналоговых доходов целесообразно усилить путем пересмотра их базы и ставок. Выяснено, что неналоговые доходы бюджетов как регулируюший инструмент сегодня используются недостаточно. Обосновань направления усиления их влияния на сочиально-экономические прочессы в Украине.

Ключевые слова: государственный бюджет, метод формирования доходов бюджетов, неналоговые доходы бюджетов, фискальная функиия, компенсаџионный характер, регулирующий инструмент.

\section{Summary}

Nataliia Bak

\section{NON-TAX BUDGET REVENUES, THEIR FUNCTIONAL IMPACT AND THE POSSIBILITIES OF ITS ACTIVATION IN UKRAINE}

The mechanism through which the authorities satisfy the need for financial resources changes during a crisis. Budget decentralization reform has become an additional factor in this process for local governments. The effectiveness of using tax and debt methods of accumulating budget resources has objective limits. Therefore, the authorities resort to the non-tax method of filling the budgets.

The purpose of the article is to reveal the substance and functional purpose of non-tax budget revenues, and to identify possibilities of their active use as an effective financial instrument.

The results of the study reveal the heterogeneity of academic views on the substance and composition of non-tax budget revenues. The necessity to change the terminology for the second group of revenues of the state budget of Ukraine to "non-tax revenues" and to organize the composition of this group in accordance with international standards is substantiated. A large variety of types of non-tax revenues determines their different functional purposes. The dominance of the fiscal function of non-tax revenues is revealed. Its further activation is possible only if the financial interests of the state and taxpayers are aligned.

Compensatory allocation of non-tax revenues is especially important for local governments. Non-tax revenues form three quarters of the special fund of local budgets. It is suggested to strengthen the compensatory role of non-tax revenues by revising their base and rates.

It was found that the regulatory purpose of non-tax budget revenues is insufficiently implemented in Ukraine today. Among the strategies and vectors to intensify the impact of non-tax budget revenues on socio-economic processes are the ensured predictability of financial relations of government with state and municipal enterprises, their highly effective management, consistency of the strategy of public financial policy at micro- and macroeconomic levels, competitive level of asset management by budget managers, encouraging higher initiative and more responsible performance of functional duties by entities that administer non-tax revenues of the State Budget of Ukraine and local budgets.

Key words: state budget, method of formation of budget revenues, non-tax budget revenues, fiscal function, compensatory character, regulatory instrument. 